[Regular Paper]

\title{
Synthesis of Liquefied Petroleum Gas via Methanol and/or Dimethyl Ether from Natural Gas (Part 2) Improvements in Catalysts for Methanol and Dimethyl Ether Conversion
}

\author{
Yingjie Jin, Sachio AsaokA*, Xiaohong LI, Kenji Asami, and Kaoru Fujimoto \\ Faculty of Environmental Engineering, The University of Kitakyushu, 1-1 Hibikino,Wakamatsu-ku, Kitakyushu 808-0135, JAPAN
}

(Received July 7, 2004)

\begin{abstract}
For the proposed synthesis of liquefied petroleum gas (LPG), MFI zeolite catalysts were prepared for selective conversion of methanol or dimethyl ether (DME) through either surface modification of parent ZSM-5 or isomorphous substitution of MFI metal heteroatoms. $\mathrm{Fe}^{3+}$-exchanged ZSM-5 was most effective to improve $\mathrm{C}_{3}-\mathrm{C}_{4}$ fractional selectivity among the surface modified H-ZSM-5 catalysts. The presence of iron, gallium and/or aluminum among the framework heteroatoms of MFI metallosilicates was correlated with improved methanol conversion to LPG hydrocarbons. Zeolites containing gallium or gallium-aluminum catalyzed methanol conversion together with aromatization. The incorporation of iron into MFI framework greatly reduced aromatization and carbon-chain growth. Zeolite containing iron and aluminum was quite effective for improving the LPG fractional selectivity. Effects of the modification procedure with iron species on catalytic performance were verified. The co-existence of iron with aluminum as heteroatoms in the MFI framework provided the best selectivity compared to ion-exchange with $\mathrm{Fe}^{3+}$ and loading of iron or oxides. DME conversion over H-FeAlMFI-silicate and unmodified H-ZSM-5 confirmed the improvement in catalytic selectivity and stability.
\end{abstract}

Keywords

Natural gas, Liquefied petroleum gas, Methanol conversion, Dimethyl ether conversion, MFI metallosilicate, Catalyst modification

\section{Introduction}

The synthesis of liquefied petroleum gas (LPG) from natural gas, especially via conversion of methanol and/or dimethyl ether (DME), has recently attracted great attention as a novel applied process ${ }^{1)}$ with different requirements for objective products and carbon sources to the conventional methanol-to-gasoline (MTG) and methanol-to-olefins (MTO) routes. The key reactions in methanol conversion to LPG hydrocarbons, which involve multistep successive reactions plus parallel reactions, can be controlled by regulation of the reaction conditions and catalytic inhibition of side reactions. Our previous studies investigated multiple zeolite catalysts for LPG synthesis, and explored the structure-reactivity relationships in the catalytic chemistry of heterogeneous catalytic conversion of methanol and/or DME2),3). H-ZSM-5 zeolite shows high selectivity for the LPG fractions due to its unusual shape selective properties in methanol conversion. Catalyst containing H-ZSM-5 zeolite provides enriched $\mathrm{C}_{3}-\mathrm{C}_{4}$

\footnotetext{
* To whom correspondence should be addressed.

* E-mail: asaoka@env.kitakyu-u.ac.jp
}

product distributions together with reduced $\mathrm{C}_{1}-\mathrm{C}_{2}$ fractions and certain $\mathrm{C}_{5}^{+}$nonaromatics plus low carbon number aromatics. The product distribution obviously depends on kinetic factors, in addition to the structural characteristics, mainly gas contact time, reaction temperature and feed partial pressure. Our studies indicated that catalysts based on zeolites with MFI structure have high potential for use in the unit process of methanol or DME conversion to LPG hydrocarbons.

Although H-ZSM-5 catalyst is very active and selective, deep transformation generally occurs during methanol conversion to hydrocarbons. In particular, sequential reactions proceed with cyclization, aromatization and aliphatic formation after complete conversion of methanol is attained, so the catalyst is degraded by coke formation. This problem will impact severely on the production of the desired $\mathrm{C}_{3}-\mathrm{C}_{4}$ hydrocarbons. Further investigation of LPG synthesis catalysts is needed to improve the catalytic performance, especially principal reaction selectivity and catalyst stability. Conventional zeolite modifications of ZSM-5 catalysts, such as ion-exchange, impregnation and isomorphous substitution of central atoms, may be effective, since these modifications have great impacts on product 
distribution in the MTO reaction ${ }^{4}$. Otherwise, little guidance is available.

The present study prepared surface modified ZSM-5 catalysts, either by ion-exchange with transition metal ions of iron, copper, chromium, rhenium, iridium, etc., or by impregnation with precursors of nonmetals such as phosphorus or fluorine. Several MFI metallosilicates, the isomorphous analogues of ZSM-5 zeolite, were synthesized by introducing iron or/and gallium compound partially or fully instead of aluminum compound into the starting gels and using ammonium fluoride as a mineralizer. These two groups of MFI zeolites, monometallosilicates and multimetallosilicates, were used to optimize the composition of framework heteroatoms. A tentative model for catalyst design was established based on the assembled modes of chosen metallic T-atoms, and the optimum combination of MFI metallic heteroatoms identified through analysis of methanol reaction results. The findings were applied to improve the performance of MFI zeolite catalysts for the selective conversion of methanol and/or DME to LPG hydrocarbons, and to investigate the effect of the combination of framework metals in the MFI structure on product distribution and catalyst stability.

\section{Experimental}

\section{1. Zeolite Synthesis and Pretreatment}

Zeolite ZSM-5 and crystalline MFI metallosilicates containing gallium, iron and/or aluminum were hydrothermally synthesized as described previously ${ }^{5)-7)}$. The resulting solid products were submitted to a standard procedure: drying at $120^{\circ} \mathrm{C}$ overnight, removal of templates by calcination in air at $550^{\circ} \mathrm{C}$ for $4 \mathrm{~h}$, ion exchange of original cations with $1 \mathrm{~N} \mathrm{NH}_{4} \mathrm{Cl}$ aqueous solution three times, collecting the ammonium-type zeolites after adequate washing and drying, and transforming into the $\mathrm{H}$-form by calcination in air at $550^{\circ} \mathrm{C}$ for $2 \mathrm{~h}$. The ZSM-5 matrices were defined as ZSM5(50) and ZSM-5(90), indicating silica-alumina ratios of about 50 and 90, respectively. The crystallinity and phase purity of the synthesized and pretreated materials were characterized by powder X-ray diffraction and Xray fluorescence spectroscopy. The framework compositions of zeolite samples were measured by ${ }^{31} \mathrm{Si}-$ MASNMR (nuclear magnetic resonance), and ESCA (electron spectroscopy for chemical analysis) with the Ar etching method.

\section{2. Catalyst Preparation}

The ammonium-type ZSM-5 was modified further, either by ion-exchange or by incipient wetness impregnation. The samples containing metal ions were prepared as follows. $10.0 \mathrm{~g} \mathrm{NH}_{4}^{+}-\mathrm{ZSM}-5(50)$ was treated at $95^{\circ} \mathrm{C}$ for $8 \mathrm{~h}$ with $300.0 \mathrm{~g}$ aqueous solution $(0.0054$ $\mathrm{M}, 1 \mathrm{M}=1 \mathrm{~mol} \cdot \mathrm{dm}^{-3}$ ) of the ion precursor (preferable nitrates or chlorides) for ion exchange equivalent to
$25 \%$ of the $\mathrm{Al}$ atom content. The samples containing fluorine or phosphorus were prepared as follows. 10.0 g $\mathrm{NH}_{4}{ }^{+}-\mathrm{ZSM}-5(50)$ was impregnated with aqueous solution $(100 \mathrm{ml})$ containing $1.62 \mathrm{mmol} \mathrm{NH}_{4} \mathrm{~F}$ or $\mathrm{H}_{3} \mathrm{PO}_{4}$. After impregnation for $24 \mathrm{~h}$, the remaining solution was slowly dried up on a water-bath. The loading amounts for the impregnated samples were about $25 \%$ of the $\mathrm{Al}$ atom content in the $\mathrm{NH}_{4}{ }^{+}-\mathrm{ZSM}-5(50)$. The catalyst samples consisted of prefabricated zeolite $(65$ wt $\%$ ) and $\mathrm{Al}_{2} \mathrm{O}_{3}$ (35 wt \%), with pseudoboehmite (Catalysts \& Chemicals Ind. Co., Ltd.) as a binder. The extrusion molding predecessors of catalysts were dried at $120^{\circ} \mathrm{C}$ for $24 \mathrm{~h}$ and calcined at $550^{\circ} \mathrm{C}$ for $8 \mathrm{~h}$, and then shaped into pellets of average $0.85 \mathrm{~mm}$ in diameter. The Fe/H-ZSM-5(90) was derived from the obtained $\mathrm{Fe}_{2} \mathrm{O}_{3} / \mathrm{H}-\mathrm{ZSM}-5(90)$ sample through in-situ $\mathrm{H}_{2}$ reduction at $450^{\circ} \mathrm{C}$ for $6 \mathrm{~h}$ before reaction tests.

\section{3. Reaction Testing}

The reaction tests for methanol or DME conversion were carried out in a slightly pressurized fixed-bed reactor at 330 or $400^{\circ} \mathrm{C}$. The stainless steel tube reactor was $300 \mathrm{~mm}$ long, with $8 \mathrm{~mm}$ inside diameter, and a $20 \mathrm{~mm}$ section in the middle was equipped with a cell of thermocouples for controlling the temperature distribution. The reaction gas mixtures consisted of methanol (or DME) and $\mathrm{N}_{2}$ with gas hourly space velocity (GHSV) of $30,000 \mathrm{~h}^{-1}$ (or $20,000 \mathrm{~h}^{-1}$ for catalyst stability tests using DME), feed partial pressure of $34 \mathrm{kPa}$ (DME) or $45 \mathrm{kPa}$ (methanol) and system pressure of 120 $\mathrm{kPa}$ at the required temperature. All products were analyzed by three gas chromatograph units on line with FID (hydrogen-flame ionization detector) and TCD (thermal conductivity detector) detectors. All reaction data used, except the on-stream tests, were uniform and obtained at $3 \mathrm{~h}$ on-stream and were calculated on a carbon basis.

\section{Results and Discussion}

\section{1. Surface Modified ZSM-5 Catalysts}

All surface modified catalysts prepared by ionexchange or impregnation of $\mathrm{NH}_{4}^{+}-\mathrm{ZSM}-5$ (50) were assessed for converting methanol to $\mathrm{C}_{3}-\mathrm{C}_{4}$ hydrocarbons at $330^{\circ} \mathrm{C}$. The relative conversion and the relative selectivity are shown in Fig. 1, with reference to the conversion and selectivity of the parent H-ZSM5(50). The activities and selectivities were lower on most surface modified catalysts compared to the unmodified H-ZSM-5(50), but the catalyst modified by $\mathrm{Fe}^{3+}$-exchange exhibited a noticeable improvement for the formation of $\mathrm{C}_{3}-\mathrm{C}_{4}$ hydrocarbons, because this catalyst obviously depressed the formation of total $\mathrm{C}_{5}^{+}$ nonaromatics and aromatics (see Fig. 2). These results provide significant information to improve the $\mathrm{C}_{3}-\mathrm{C}_{4}$ fractional selectivity by introducing appropriate metal species into the catalyst. In fact, some metal- 


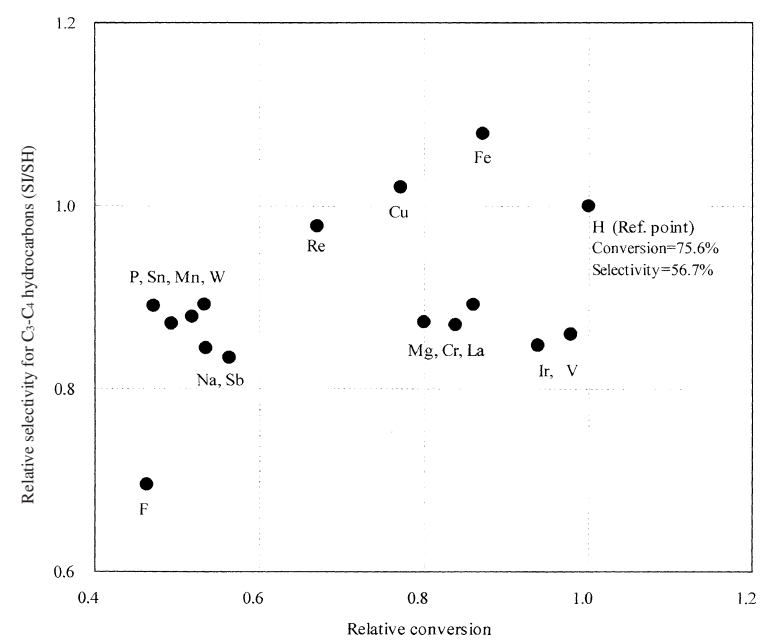

Reaction conditions

methanol partial pressure: $45 \mathrm{kPa}$, total pressure: $120 \mathrm{kPa}$, GHSV: $30,000 \mathrm{~h}^{-1}$, temperature: $330^{\circ} \mathrm{C}$ (loading amounts or exchange ratios for all samples correspond to $25 \%$ of framework $\mathrm{Al} ; \mathrm{SI} / \mathrm{SH}$ is the ratio of selectivities for $\mathrm{C}_{3}-\mathrm{C}_{4}$ hydrocarbons for each sample compared to H-ZSM-5).

Fig. 1 Methanol Conversion over Various Surface Modified $\mathrm{H}-\mathrm{ZSM}-5\left(\mathrm{SiO}_{2} / \mathrm{Al}_{2} \mathrm{O}_{3}=50\right)$ Catalysts

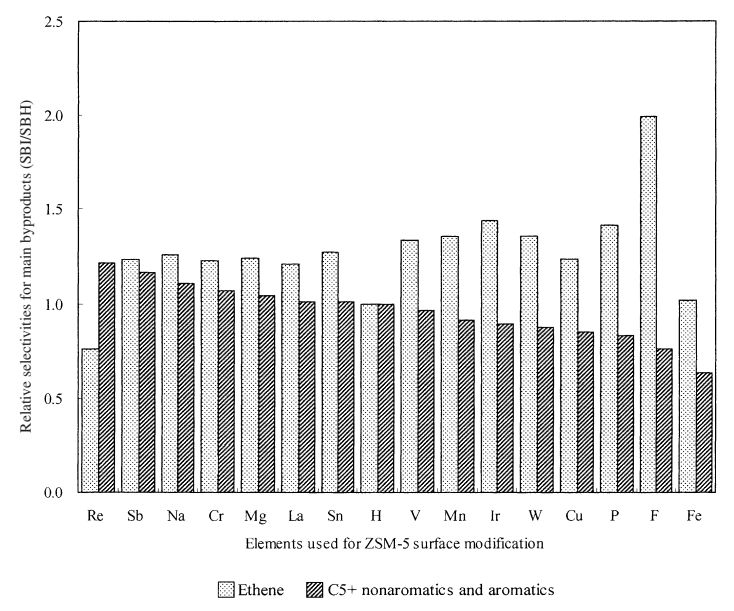

SBI/SBH refers the ratio of selectivities to ethene or total aromatics plus nonaromatics for each sample compared to H-ZSM-5.

Fig. 2 Relative Selectivity of Ethene or Total Aromatics and $\mathrm{C}_{5}{ }^{+}$Nonaromatics Compared to Results Obtained on Matrix H-ZSM-5 $\left(\mathrm{SiO}_{2} / \mathrm{Al}_{2} \mathrm{O}_{3}=50\right)$ Catalyst at $330^{\circ} \mathrm{C}$

incorporated MFI zeolite catalysts targeted at objective reaction selectivity were suggested for continuous study. Figure 2 clearly shows the order in reduction of selectivity for total aromatics and $\mathrm{C}_{5}{ }^{+}$nonaromatics for all surface modified catalysts, regardless of differences in ethene selectivity. In the proposed LPG process, such heavier products are formed almost irreversibly but ethene-rich $\mathrm{C}_{2}$ hydrocarbons may be converted into LPG fractions through a recycling process.

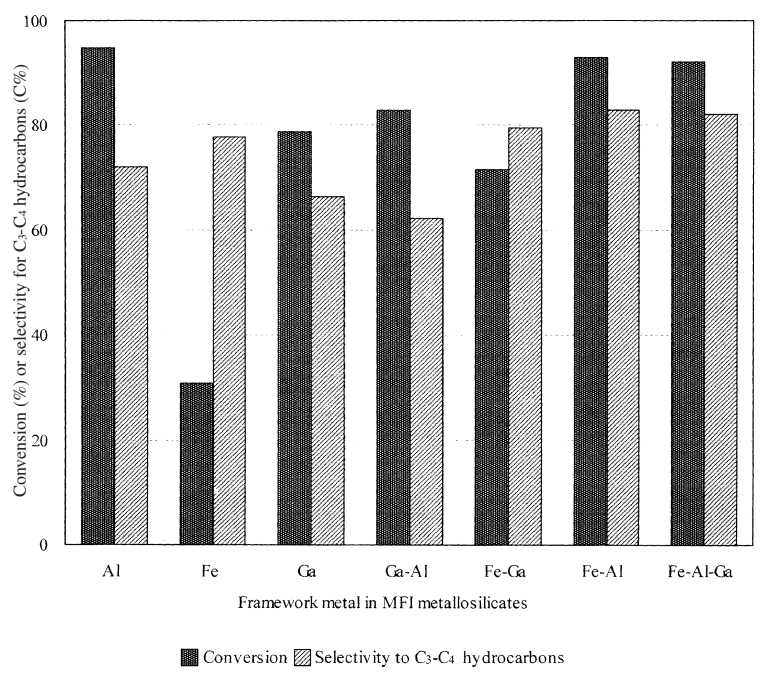

methanol partial pressure: $45 \mathrm{kPa}$, total pressure: $120 \mathrm{kPa}$, $\mathrm{GHSV}=30,000 \mathrm{~h}^{-1}$, temperature: $400^{\circ} \mathrm{C}$.

Fig. 3 Methanol Conversion over Various MFI Metallosilicate Catalysts under Reaction Conditions

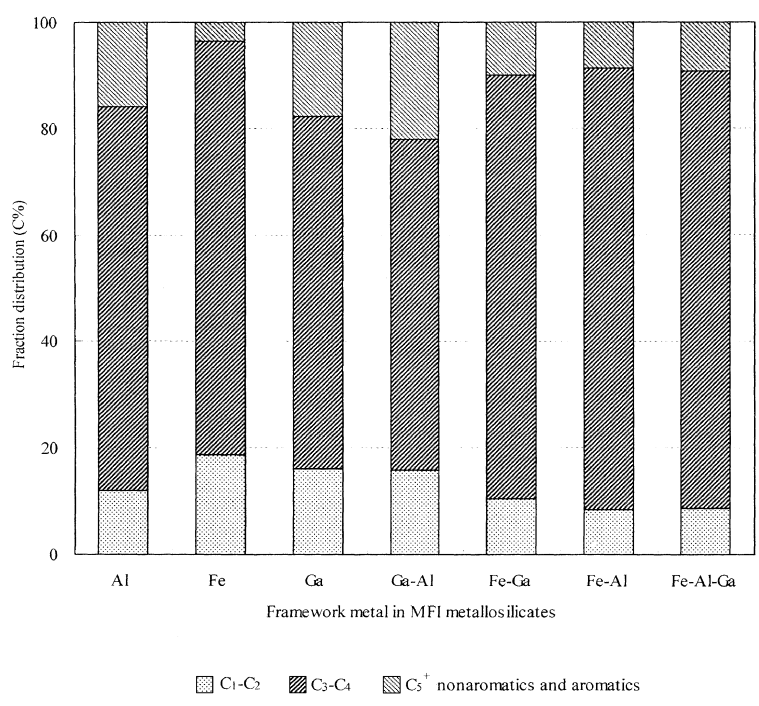

Fig. 4 Fraction Distribution of Methanol Transformation over MFI Metallosilicate Catalysts at $400^{\circ} \mathrm{C}$

Moreover, all modified catalysts, except iron- and rhenium-containing types, are selective for ethene rather than propene and butene formation, and the high ethene selectivity is always associated with low selectivity for aromatics and $\mathrm{C}_{5}^{+}$nonaromatics, especially in the fluorine-, phosphorus- or iridium-treated catalysts. The H-ZSM-5(50) catalyst modified by iron had the greatest $\mathrm{C}_{3}-\mathrm{C}_{4}$ fractional selectivity among the surface modified ZSM-5(50) catalysts.

\section{2. MFI-metallosilicate Catalysts}

Figures 3 and 4 summarize the results of methanol conversion at $400^{\circ} \mathrm{C}$ over H-ZSM-5(90) and protonated 
Table 1 Methanol Conversion to LPG Hydrocarbons over H-ZSM-5(90) and Various MFI Metallosilicate Catalysts

\begin{tabular}{|c|c|c|c|c|c|c|c|c|}
\hline MFI framework metal & & $\mathrm{Al}$ & $\mathrm{Fe}$ & $\mathrm{Ga}$ & $\mathrm{Ga}-\mathrm{Al}$ & $\mathrm{Fe}-\mathrm{Ga}$ & $\mathrm{Fe}-\mathrm{Al}$ & $\mathrm{Fe}-\mathrm{Ga}-\mathrm{Al}$ \\
\hline Framework composition & & $\mathrm{Si}: \mathrm{Al}$ & $\mathrm{Si}: \mathrm{Fe}$ & $\mathrm{Si}: \mathrm{Ga}$ & $\mathrm{Si}: \mathrm{Ga}: \mathrm{Al}$ & $\mathrm{Si}: \mathrm{Fe}: \mathrm{Ga}$ & $\mathrm{Si}: \mathrm{Fe}: \mathrm{Al}$ & Si: Fe: Ga: Al \\
\hline (atomic mole ratio) & & $45: 1$ & $47: 1$ & $45: 1$ & $45: 0.2: 0.8$ & $45: 0.2: 0.8$ & $47: 0.2: 0.8$ & $47: 0.2: 0.2: 0.6$ \\
\hline Methanol conversion & {$[\%]$} & 94.9 & 30.8 & 78.9 & 82.9 & 71.5 & 93.1 & 92.3 \\
\hline Yield of LPG hydrocarbons & {$[\mathrm{C} \%]$} & 68.4 & 23.9 & 52.5 & 51.6 & 56.9 & 77.4 & 75.8 \\
\hline \multicolumn{9}{|c|}{ Hydrocarbon distribution $\quad[\mathrm{C} \%]$} \\
\hline Methane & & 0.7 & 7.9 & 1.4 & 2.0 & 2.0 & 1.6 & 1.3 \\
\hline Ethane & & 0.1 & 0.0 & 0.4 & 0.3 & 0.1 & 0.0 & 0.1 \\
\hline Ethene & & 11.3 & 10.9 & 14.2 & 13.5 & 8.5 & 6.7 & 7.3 \\
\hline Propane & & 3.0 & 0.4 & 4.3 & 5.3 & 0.4 & 0.7 & 1.0 \\
\hline Propene & & 35.5 & 50.4 & 35.7 & 29.2 & 47.4 & 53.7 & 49.8 \\
\hline Butanes & & 13.8 & 1.8 & 12.5 & 12.9 & 5.6 & 3.6 & 4.2 \\
\hline Butenes & & 19.8 & 25.1 & 14.0 & 14.9 & 25.2 & 25.1 & 27.1 \\
\hline $\mathrm{C}_{5}{ }^{+}$nonaromatics & & 6.7 & 1.6 & 5.2 & 6.8 & 3.7 & 3.5 & 4.1 \\
\hline Aromatics & & 9.2 & 2.1 & 12.3 & 15.2 & 6.1 & 5.1 & 5.2 \\
\hline Total & & 100 & 100 & 100 & 100 & 100 & 100 & 100 \\
\hline $\mathrm{C}_{1}-\mathrm{C}_{2}$ hydrocarbons & {$[\mathrm{C} \%]$} & 12.0 & 18.7 & 16.0 & 15.8 & 10.6 & 8.3 & 8.7 \\
\hline $\mathrm{C}_{3}-\mathrm{C}_{4}$ hydrocarbons & {$[\mathrm{C} \%]$} & 72.0 & 77.7 & 66.5 & 62.2 & 79.6 & 83.1 & 82.1 \\
\hline $\begin{array}{c}\mathrm{C}_{5}+\text { nonaromatics } \\
\text { and aromatics }\end{array}$ & {$[\mathrm{C} \%]$} & 15.9 & 3.6 & 17.4 & 22.0 & 9.8 & 8.6 & 9.3 \\
\hline $\mathrm{C}_{3} /\left(\mathrm{C}_{3}+\mathrm{C}_{4}\right)$ & {$[\mathrm{C} \%]$} & 53.4 & 65.4 & 60.1 & 55.4 & 61.4 & 65.4 & 61.9 \\
\hline Paraffin in LPG fraction & {$[\mathrm{C} \%]$} & 23.3 & 2.8 & 25.2 & 29.2 & 7.5 & 5.2 & 6.3 \\
\hline
\end{tabular}

Reaction temperature: $400^{\circ} \mathrm{C}$; GHSV $=30,000 \mathrm{~h}^{-1}$; carrier gas: $\mathrm{N}_{2}$; methanol partial pressure: $45 \mathrm{kPa}$; total pressure: $120 \mathrm{kPa}$.

MFI metallosilicate catalysts. Detailed results are compiled in Table 1. H-ZSM-5(90) catalyst achieved almost complete conversion of methanol, together with more than $70 \%$ selectivity for the $\mathrm{C}_{3}-\mathrm{C}_{4}$ fraction. $\mathrm{H}$ GaMFI-silicate gave methanol conversion of less than $80 \%$ and $\mathrm{C}_{3}-\mathrm{C}_{4}$ fractional selectivity close to $70 \%$, but also promoted aromatization compared to H-FeMFI-silicate and H-ZSM-5(90). Incorporation of iron in MFI-silicate, i.e. H-FeMFI-silicate, remarkably improved the $\mathrm{C}_{3}-\mathrm{C}_{4}$ fractional selectivity by reducing aromatic and $\mathrm{C}_{5}{ }^{+}$nonaromatic products. H-FeMFI-silicate promoted the side reaction of methanation to a large extent and as a result low methanol conversion was low. The poor activity may be attributed to the weak acidity of the MFI-silicate that contains iron as the only metallic T-atom. Nevertheless, the extremely low selectivity for the heavy byproducts was indicative of the usefulness of iron species in MFI-silicates, since framework iron restricts shifts of $\mathrm{C}_{3}-\mathrm{C}_{4}$ olefinic intermediates to heavy products and reduces the subsequent cyclization and aromatization reactions, as known in MTO technology ${ }^{8)}$.

In bimetallic and multi-metallic silicates, gallium as a partial replacement for aluminum in the MFI framework reduced methanol conversion, probably as a result of the increased acidity of the gallium central atoms ${ }^{9)}$, and also reduced $\mathrm{C}_{3}-\mathrm{C}_{4}$ fraction selectivity due to the promotion of dehydrogenation aromatization of the heavier olefins, which is the impetus to increase light olefin saturation. This observation discloses the presence of intermolecular hydrogen transfer reactions associated with dehydrogenation and hydrogen abstraction in the methanol reaction. These hydrogen trans- fer reactions, which also occur in the H-ZSM-5(90) catalytic system, induce the formation of aromatics and light paraffins, and further the carbon-chain growth of propene and butenes. By contrast, iron as a partial replacement of either aluminum or gallium in the MFI framework effectively reduces the aromatization reaction and obviously improves major product selectivity. In particular, the aromatic content is reduced over $\mathrm{H}$ FeGaMFI-silicate despite the presence of active gallium for aromatization compared to H-ZSM-5(90)[HAlMFI-silicate] ${ }^{10)}$. These results indicate that, in coexistence with gallium and/or aluminum, iron species in MFI metallosilicates always have an excellent inhibiting effect on the aromatization reaction in the methanol-tohydrocarbons reaction, although the inhibiting effect is partially attributed to decreased methanol conversion.

H-FeAlMFI-silicate achieves higher conversion of methanol and selectivity for LPG hydrocarbons than HFeGaMFI and H-FeGaAlMFI-silicates. These characteristics may result essentially from variations in the acidity of these MFI metallosilicates. The different central heteroatoms in the metallosilicates have presumably already created various electrostatic and chemical conditions owing to the intrinsic metallicity of these metallic heteroatoms. Therefore, suitable acid sites are available for methanol reaction and to control the catalytic action of the catalysts. In fact, the methanol-to-hydrocarbons reaction does not require strong acid centers, which generally result in undesirable deep conversion as well as coke formation ${ }^{4}$. Aluminum species in the MFI framework provide the strong acid sites that can catalyze almost all reactions 
Table 2 DME Conversion to LPG Hydrocarbons over H-ZSM-5(90) and Various MFI Metallosilicate Catalysts

\begin{tabular}{|c|c|c|c|c|c|c|c|c|}
\hline \multicolumn{2}{|l|}{ MFI framework metal } & $\mathrm{Al}$ & $\mathrm{Fe}$ & $\mathrm{Ga}$ & $\mathrm{Ga}-\mathrm{Al}$ & $\mathrm{Fe}-\mathrm{Ga}$ & $\mathrm{Fe}-\mathrm{Al}$ & $\mathrm{Fe}-\mathrm{Ga}-\mathrm{Al}$ \\
\hline Framework composition & & $\mathrm{Si}: \mathrm{Al}$ & $\mathrm{Si}: \mathrm{Fe}$ & $\mathrm{Si}: \mathrm{Ga}$ & $\mathrm{Si}: \mathrm{Ga}: \mathrm{Al}$ & $\mathrm{Si}: \mathrm{Fe}: \mathrm{Ga}$ & $\mathrm{Si}: \mathrm{Fe}: \mathrm{Al}$ & Si: Fe: Ga: Al \\
\hline (atomic mole ratio) & & $45: 1$ & $47: 1$ & $45: 1$ & $45: 0.2: 0.8$ & $45: 0.2: 0.8$ & $47: 0.2: 0.8$ & $47: 0.2: 0.2: 0.6$ \\
\hline DME conversion & [\%] & 92.4 & 28.6 & 72.6 & 78.3 & 57.9 & 86.9 & 84.8 \\
\hline Yield of LPG hydrocarbons & {$[\mathrm{C} \%]$} & 67.8 & 21.0 & 49.7 & 48.9 & 45.6 & 70.8 & 68.3 \\
\hline Hydrocarbon distribution & {$[\mathrm{C} \%]$} & & & & & & & \\
\hline Methane & & 1.3 & 7.5 & 1.5 & 1.7 & 1.5 & 1.1 & 1.2 \\
\hline Ethane & & 0.1 & 1.0 & 0.3 & 0.3 & 0.0 & 0.0 & 0.1 \\
\hline Ethene & & 11.8 & 10.6 & 10.2 & 9.7 & 5.9 & 6.8 & 7.0 \\
\hline Propane & & 3.2 & 0.3 & 3.8 & 5.1 & 0.7 & 0.9 & 1.6 \\
\hline Propene & & 37.9 & 48.5 & 33.1 & 27.7 & 46.1 & 51.6 & 45.4 \\
\hline Butanes & & 12.3 & 2.2 & 11.4 & 14.1 & 5.9 & 4.7 & 4.9 \\
\hline Butenes & & 19.9 & 22.4 & 20.5 & 15.6 & 26.0 & 24.3 & 28.7 \\
\hline $\mathrm{C}_{5}{ }^{+}$nonaromatics & & 7.1 & 2.6 & 6.2 & 6.8 & 5.5 & 4.3 & 4.6 \\
\hline Aromatics & & 6.5 & 4.8 & 13.4 & 19.0 & 8.2 & 6.4 & 6.6 \\
\hline Total & & 100 & 100 & 100 & 100 & 100 & 100 & 100 \\
\hline $\mathrm{C}_{1}-\mathrm{C}_{2}$ hydrocarbons & {$[\mathrm{C} \%]$} & 13.2 & 19.2 & 12.0 & 11.7 & 7.6 & 7.9 & 8.2 \\
\hline $\mathrm{C}_{3}-\mathrm{C}_{4}$ hydrocarbons & {$[\mathrm{C} \%]$} & 73.3 & 73.4 & 68.5 & 62.5 & 78.7 & 81.4 & 80.6 \\
\hline $\begin{array}{c}\mathrm{C}_{5}{ }^{+} \text {nonaromatics } \\
\text { and aromatics }\end{array}$ & {$[\mathrm{C} \%]$} & 13.6 & 7.4 & 19.6 & 25.9 & 13.7 & 10.7 & 11.2 \\
\hline $\mathrm{C}_{3} /\left(\mathrm{C}_{3}+\mathrm{C}_{4}\right)$ & {$[\mathrm{C} \%]$} & 56.1 & 66.5 & 53.9 & 52.5 & 59.5 & 64.4 & 58.4 \\
\hline Paraffin in LPG fraction & {$[\mathrm{C} \%]$} & 21.1 & 3.4 & 21.8 & 30.7 & 8.4 & 6.8 & 8.1 \\
\hline
\end{tabular}

Reaction temperature: $400^{\circ} \mathrm{C}$; GHSV: $30,000 \mathrm{~h}^{-1}$; carrier gas: $\mathrm{N}_{2}$; DME partial pressure: $34 \mathrm{kPa}$; total pressure: $120 \mathrm{kPa}$.

during methanol conversion, but some acid sites derived from gallium are much more effective for cyclization-dehydrogenation of olefins, and the effect is enlarged by the cooperation of gallium with aluminum. The acid sites evolved from framework iron do not seem to favor the olefin cyclization reaction, most probably because of their relatively weak acidity ${ }^{11)}$. Therefore, the iron sites may impair the following dehydrogenation-aromatization reaction. Unfortunately, they do not allow complete conversion of methanol. Isomorphous part substitution of iron for aluminum is more effective, by which moderate acid sites are generated as the ensemble of iron and aluminum in the framework, in contrast to the Fe-MFI-silicate and AlMFI-silicate mixture. Such a structure can achieve adequate conversion of methanol and minimize aromatization and methanation reactions.

Table 1 shows the $\mathrm{C}_{3}$ hydrocarbon or paraffin components in the LPG hydrocarbons. The $\mathrm{C}_{3}$ content in the synthesized $\mathrm{C}_{3}-\mathrm{C}_{4}$ hydrocarbons is one of the basic specifications that characterize the volatility and combustibility of the final LPG products. Higher $\mathrm{C}_{3}$ hydrocarbon content results in a more volatile and flammable synthetic fuel. The catalytic performance of the catalysts is related to the $\mathrm{C}_{3}-\mathrm{C}_{4}$ hydrocarbon saturation and aromatic content. For example, H-ZSM5(90), H-GaMFI-silicate and H-GaAlMFI-silicate promote the formation of $\mathrm{C}_{3}-\mathrm{C}_{4}$ hydrocarbons with increasing paraffin content, but also result in serious aromatization compared to the other MFI metallosilicates. The bimetallic H-GaAlMFI-silicate, especially, is associated with disastrous aromatizing side reactions.
After iron species are introduced into the MFI framework, $\mathrm{C}_{3}-\mathrm{C}_{4}$ hydrocarbon saturation and the aromatic content are both reduced, and $\mathrm{C}_{3}-\mathrm{C}_{4}$ fractional selectivity is greatly increased. These results further demonstrate the deactivation effect of framework iron on the conjugated hydrogen transfer reactions.

The results of DME reaction over these MFI metallosilicate catalysts are shown in Table 2 . The reaction behavior of DME was very comparable with that of methanol over the same catalyst, except for slightly lower conversions under similar reaction conditions. For both methanol and DME transformations, HFeAlMFI-silicate catalyst was the most effective promoter of LPG synthesis among all MFI metallosilicate catalysts.

\section{3. Effective Modification with Iron Species}

To investigate the involvement of various iron species in iron-MFI-silicates as active components in the methanol reaction, a series of iron-containing catalysts were prepared and tested under a nitrogen atmosphere. $\mathrm{H}\left(\mathrm{Fe}^{3+}\right)-\mathrm{ZSM}-5(90)$ was prepared by exchanging $\mathrm{NH}_{4}{ }^{+}-\mathrm{ZSM}-5(90)$ with aqueous solution containing $\mathrm{Fe}^{3+}$ equivalent to about $25 \%$ of framework aluminum atoms. $\mathrm{Fe}_{2} \mathrm{O}_{3} / \mathrm{H}-\mathrm{ZSM}-5(90)$ and Fe/H-ZSM-5(90), containing the same iron amount as $\mathrm{H}\left(\mathrm{Fe}^{3+}\right)-\mathrm{ZSM}-$ 5(90), were prepared based on the impregnation of $\mathrm{H}$ ZSM-5(90). Table 3 shows that, in comparison with H-ZSM-5(90), H-FeAlMFI-silicate and H(Fe $\left.{ }^{3+}\right)$ ZSM5(90) catalysts had increased selectivities for total LPG hydrocarbons, with increases in propene and butenes, and decreases in ethene and aromatics. Fe/H-ZSM5(90) and $\mathrm{Fe}_{2} \mathrm{O}_{3} / \mathrm{H}-\mathrm{ZSM}-5(90)$ also facilitated the for- 
Table 3 Methanol Conversion to LPG Hydrocarbons over Surface Modified H-ZSM-5(90) and H-FeAlMFI-silicate Catalysts ${ }^{\text {a) }}$

\begin{tabular}{|c|c|c|c|c|c|c|}
\hline \multicolumn{2}{|l|}{ Catalysts and preparation ${ }^{\text {b) }}$} & $\begin{array}{l}\text { H-FeAlMFI-silicate } \\
\text { Fe in framework }\end{array}$ & $\begin{array}{c}\mathrm{H}\left(\mathrm{Fe}^{3+}\right)-\mathrm{ZSM}-5(90) \\
\text { ion-exchange }\end{array}$ & $\begin{array}{l}\mathrm{Fe} / \mathrm{H}-\mathrm{ZSM}-5(90) \\
\text { impregnation }\end{array}$ & $\begin{array}{c}\mathrm{Fe}_{2} \mathrm{O}_{3} / \mathrm{H}-\mathrm{ZSM}-5(90) \\
\text { impregnation }\end{array}$ & $\begin{array}{l}\text { H-ZSM-5 }(90) \\
\text { Fe-free matrix }\end{array}$ \\
\hline \multicolumn{2}{|l|}{ Ratio of Fe to framework $\mathrm{Al}$} & 0.25 & ca. 0.25 & 0.25 & 0.25 & 0.0 \\
\hline Methanol conversion & [\%] & 93.1 & 91.5 & 89.8 & 81.8 & 94.9 \\
\hline Yield of LPG hydrocarbons & {$[\mathrm{C} \%]$} & 77.4 & 70.0 & 63.9 & 55.5 & 68.4 \\
\hline \multicolumn{7}{|c|}{ Hydrocarbon distribution $\quad[\mathrm{C} \%]$} \\
\hline Methane & & 1.6 & 0.9 & 0.9 & 1.3 & 0.7 \\
\hline Ethane & & 0.0 & 0.1 & 0.1 & 0.1 & 0.1 \\
\hline Ethene & & 6.7 & 10.3 & 11.9 & 11.1 & 11.3 \\
\hline Propane & & 0.7 & 2.3 & 2.6 & 2.3 & 3.0 \\
\hline Propene & & 53.7 & 42.2 & 40.5 & 39.5 & 35.5 \\
\hline Butanes & & 3.6 & 9.6 & 10.7 & 10.1 & 13.8 \\
\hline Butenes & & 25.1 & 22.5 & 17.4 & 16.7 & 19.8 \\
\hline $\mathrm{C}_{5}{ }^{+}$nonaromatics & & 3.5 & 6.7 & 6.8 & 7.2 & 6.7 \\
\hline Aromatics & & 5.1 & 5.6 & 9.3 & 11.9 & 9.2 \\
\hline Total & & 100 & 100 & 100 & 100 & 100 \\
\hline $\mathrm{C}_{1}-\mathrm{C}_{2}$ hydrocarbons & [C\%] & 8.3 & 11.2 & 12.8 & 12.4 & 12.0 \\
\hline $\mathrm{C}_{3}-\mathrm{C}_{4}$ hydrocarbons & {$[\mathrm{C} \%]$} & 83.1 & 76.5 & 71.1 & 68.5 & 72.0 \\
\hline \multicolumn{7}{|l|}{$\mathrm{C}_{5}{ }^{+}$nonaromatics } \\
\hline and aromatics & {$[\mathrm{C} \%]$} & 8.6 & 12.3 & 16.0 & 19.1 & 15.9 \\
\hline $\mathrm{C}_{3} /\left(\mathrm{C}_{3}+\mathrm{C}_{4}\right)$ & {$[\mathrm{C} \%]$} & 65.4 & 58.1 & 60.6 & 60.9 & 53.4 \\
\hline Paraffin in LPG fraction & {$[\mathrm{C} \%]$} & 5.2 & 15.5 & 18.7 & 18.0 & 23.3 \\
\hline
\end{tabular}

a) Reaction temperature: $400^{\circ} \mathrm{C}$; GHSV $=30,000 \mathrm{~h}^{-1}$; carrier gas: $\mathrm{N}_{2}$; methanol partial pressure: $45 \mathrm{kPa}$; total pressure: $120 \mathrm{kPa}$.

b) $\mathrm{H}\left(\mathrm{Fe}^{3+}\right)-\mathrm{ZSM}-5(90)$ is prepared by exchanging $\mathrm{NH}_{4}{ }^{+}-\mathrm{ZSM}-5(90)$ with the aqueous solution with $\mathrm{Fe}^{3+}$ amount related to about $25 \%$ of framework Al; H-ZSM-5(90) is impregnated by $\mathrm{Fe}^{3+}$ aqueous solution, in which the $\mathrm{Fe}^{3+}$ amount is corresponding to $25 \%$ of framework $\mathrm{Al}$, followed by calcination at $550^{\circ} \mathrm{C}$ for $8 \mathrm{~h}$ to obtain the $\mathrm{Fe}_{2} \mathrm{O}_{3} / \mathrm{H}-\mathrm{ZSM}-5(90)$ and $\mathrm{H}_{2}$ reduction at $450^{\circ} \mathrm{C}$ for $6 \mathrm{~h}$ to the $\mathrm{Fe} / \mathrm{H}-\mathrm{ZSM}-5(90)$.

mation of propene, but only slightly improved methanol conversion and LPG fractional selectivity. No change in product distribution was observed over $\mathrm{Fe} / \mathrm{H}-\mathrm{ZSM}-5(90)$ catalyst using hydrogen as the carrier gas. Of the four iron-containing catalysts prepared by different methods, the catalyst containing iron in the MFI framework was the most effective for modifying the selectivity of methanol conversion to LPG hydrocarbons. The presence of iron in $\mathrm{H}\left(\mathrm{Fe}^{3+}\right)-\mathrm{ZSM}-5(90)$ also caused improved catalyst selectivity despite a small loss in activity. However, the loadings of metallic iron or oxides on H-ZSM-5(90) were confirmed to depress catalytic activity. The loss in activity can be attributed to a decrease in acid sites as a result of covering by iron clusters or oxides. No enhanced aromatizing activity for the Fe/H-ZSM-5(90) catalyst was observed, probably implying that aromatization activity firstly depends on the initial cyclization capacity of catalysts rather than the hydrogen transfer function. Further work is in progress on why iron incorporated in the MFI framework favors the formation of $\mathrm{C}_{3}-\mathrm{C}_{4}$ olefins.

\section{4. Long-term Runs}

The H-ZSM-5(90) and H-FeAlMFI-silicate catalysts were compared for DME conversion to LPG hydrocarbons. Figures $\mathbf{5}$ and $\mathbf{6}$ show the conversion and fraction distribution as functions of time on-stream. Figure 7 shows variations of LPG fractional $\mathrm{C}_{3}$ content and saturation with time on-stream.

Under the set reaction conditions, H-ZSM-5(90) and

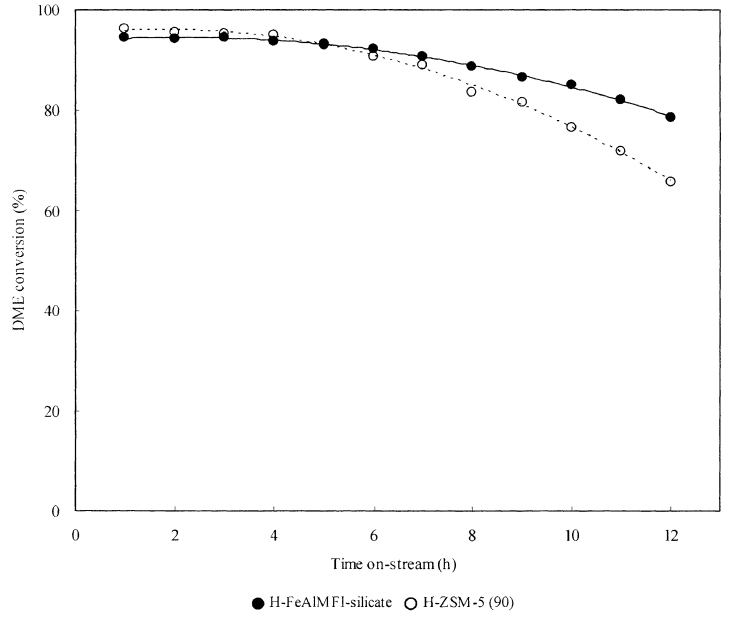

Reaction conditions temperature: $400^{\circ} \mathrm{C}$, GHSV: $20,000 \mathrm{~h}^{-1}$, DME partial pressure: $34 \mathrm{kPa}$, total pressure: $120 \mathrm{kPa}$.

Fig. 5 DME Conversion as a Function of Time On-stream

H-FeAlMFI-silicate catalysts had the nearly same initial activity in terms of DME conversion, but H-ZSM5(90) suffered from fast deactivation due to rapid coking in the long-term run, whereas H-FeAlMFI-silicate revealed improved stability, indicating that iron incorporation in the MFI structure promotes resistance to coke formation during DME conversion to hydrocarbons. This finding can be related to the fraction distri- 


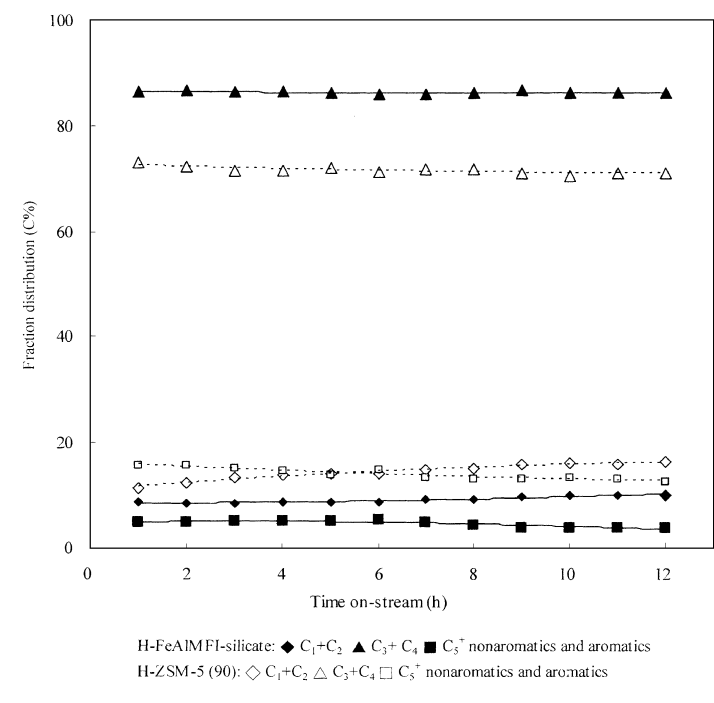

Fig. 6 Fraction Distribution with Time On-stream

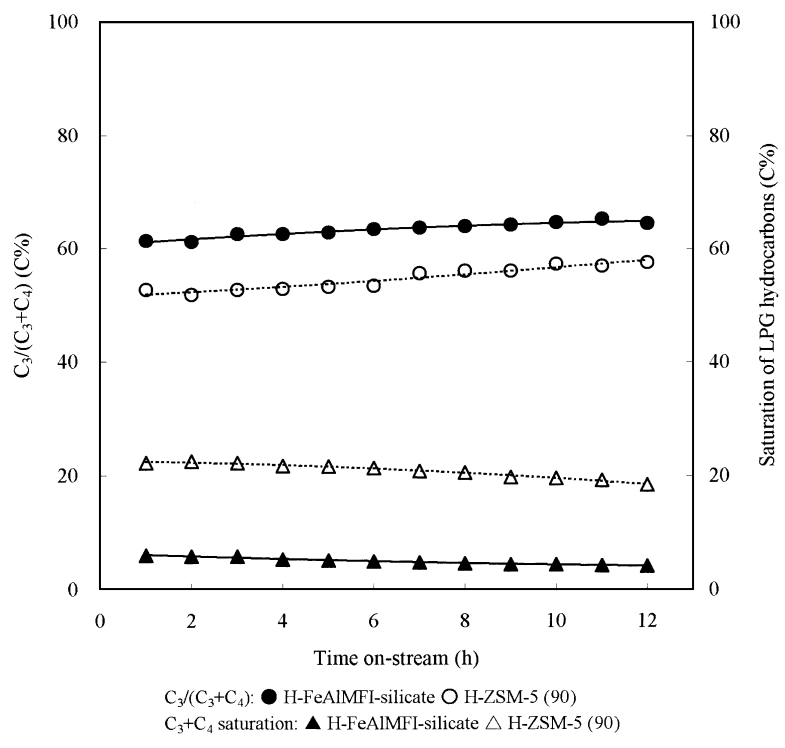

Fig. $7 \mathrm{C}_{3}$ Content in LPG Hydrocarbons and Saturation of LPG Hydrocarbons with Time On-stream

bution for each catalyst. The modified stability of $\mathrm{H}$ FeAlMFI-silicate catalyst is associated with the lower selectivity for the heavy fraction, especially the aromatics, which are generally regarded as coke precursors. The progressive stability can be mainly attributed to the lower Brönsted acidity of H-FeAlMFI-silicate ${ }^{12)}$, which generally decreases the coking rate. Iron in the MFI framework suffers from removal and generates iron oxide clusters linked to the zeolite framework during the coupled methanol-hydrocarbon cracking reaction ${ }^{13)}$. In contrast, iron in the MFI framework of the $\mathrm{H}$ FeAlMFI-silicate catalyst seemed to be very stable during the long-term run with largely formed water. This is supported by comparison of the results in Table 3 and Fig. 6, since no correlation in fraction distribution was observed between $\mathrm{Fe}_{2} \mathrm{O}_{3} / \mathrm{H}-\mathrm{ZSM}-5$ (90) and the engaged H-FeAlMFI-silicate. The decrease in conversion (Fig. 5) with time on-stream is mainly attributed to coking but not to removal of framework iron.

H-ZSM-5(90) and H-FeAlMFI-silicate showed a great contrast in fraction distributions. H-FeAlMFIsilicate always had higher selectivity for the $\mathrm{C}_{3}-\mathrm{C}_{4}$ fraction and fewer byproducts than H-ZSM-5(90) with time on-stream. In addition to the good stability and selectivity, H-FeAlMFI-silicate converted DME into LPG hydrocarbons with higher content of the desirable $\mathrm{C}_{3}$ components compared with H-ZSM-5(90). For both catalysts, the total $\mathrm{C}_{3}$ contents in the LPG fractions increased gradually with time on-stream. The LPG fractions almost totally consisted of $\mathrm{C}_{3}-\mathrm{C}_{4}$ olefins. However, the saturation of the LPG fraction associated with H-FeAlMFI-silicate was quite low, due to a lower ratio of aromatics in the total hydrocarbon product considering the hydrogen transfer and balance.

\section{Conclusions}

Surface modified and isomorphously substituted ZSM-5 catalysts were investigated to improve the performance of LPG synthesis catalysts. Methanol conversion over ion exchanged or impregnated ZSM-5 catalysts showed that $\mathrm{Fe}^{3+}$-exchanged ZSM-5 had remarkably increased $\mathrm{C}_{3}-\mathrm{C}_{4}$ fractional selectivity. For mono- and bimetallic MFI-silicate catalysts, the $\mathrm{H}$ GaMFI-silicate catalyzed methanol conversion with considerable aromatization, and this effect was enlarged by the combination of gallium with aluminum. The incorporation of iron into the MFI framework minimized both aromatization and carbon-chain growth, and the introduction of aluminum into FeMFI or FeGaMFI frameworks greatly increased catalytic activity for methanol conversion. The reaction results with various iron species indicated that iron in the MFI framework is the most effective of the ionic, metallic and oxide states. DME conversion over the $\mathrm{H}$ FeAlMFI-silicate and the unmodified H-ZSM-5 catalysts confirmed the improvement in the selectivity and stability, and the LPG hydrocarbons formed over $\mathrm{H}$ FeAlMFI-silicate consisted of enriched propene.

\section{Acknowledgments}

We would like to acknowledge the financial support provided by the Japan Gas Synthesis Ltd. for this work.

\section{References}

1a) Fujimoto, K., Saima, H., Tominaga, H., J. Catal., 94, 16 (1985).

1b) Fujimoto, K., 8th Japan-China Symposium on Coal and $\mathrm{C}_{1}$ Chemistry, (2003).

2) Jin, Y., Asaoka, S., Li, X., Asami, K., Fujimoto, K., Fuel Process. Tech., 85, (8-10), 1151 (2004). 
3) Jin, Y., Asaoka, S., Li, X., Asami, K., Fujimoto, K., J. Jpn. Petrol. Inst., 47, (6), 394 (2004).

4) Stocker, M., Micropor. Mesopor. Mater., 29, 3 (1999).

5) Gabelica, Z., Valange, S., Micropor. Mesopor. Mater., 30, 57 (1999).

6) Mochida, I., Eguchi, S., Hironaka, M., Nagao, S.-I., Sakanishi, K., Whitehurst, D., Zeolites, 18, 142 (1997).

7) Testa, F., Pasqua, L. S., Crea, F. et al., Micropor. Mesopor. Mater., 57, 57 (2003)

8a) Inui, T., in: Grasselli, R. K., Sleight, A. W. (eds.), "StructureActivity and Selectivity Relationships in Heterogeneous Catalysis," Elsevier, Amsterdam (1991), p. 233. 8b) Inui, T., Sekiyu Gakkaishi (J. Jpn. Petrol. Inst.), 35, (1), 33 (1992).

9) Choudhary, V. R., Mulla, S. A. R., Banerjee, S., Micropor. Mesopor. Mater., 57, 317 (2003).

10) Choudhary, V. R., Devadas, P., Banerjee, S., Kinage, A. K., Micropor. Mesopor. Mater., 47, 253 (2001).

11) Martin, A., Nowak, S., Wieker, W., Fahlke, B., Appl. Catal., 57, 203 (1990).

12) Martin, A., Nowak, S., Lucke, B., Wieker, W., Fahlke, B., Stud. Surf. Sci. Catal., 65, 315 (1991).

13) Lucke, B., Martin, A., Gunschel, H., Nowak, S., Micropor. Mesopor. Mater., 29, 145 (1999).

要旨

\title{
天然ガスからメタノールおよび/あるいはジメチルエーテル経由での液化石油ガス製造 （第2 報）メタノールおよびジメチルエーテル転化における触媒改良
}

\author{
金 英傑, 浅岡 佐知夫，黎 暁紅，朝見 賢二，藤元 薰 \\ 北九州市立大学国際環境工学部，808-0135 北九州市若松区ひびきの1-1
}

\begin{abstract}
提案しているメタノールおよび/あるいはジメチルエーテル （DME）経由の液化石油ガス（LPG）合成法に関して，メ夕 ノールあるいは DMEを LPG 成分に選択的に転化する ZSM-5 触 媒を，表面修飾（イオン交換，金属担持）あるいはMFI骨格 元素存在（メタロシリケートにする方法）によって改良するこ とを試みた。表面修飾では Fe（III）のイオン交換が，骨格元素 存在では $\mathrm{Fe}$ と $\mathrm{Al}$ との共存が効果的であった。 $\mathrm{Ga}$ 含有 $(\mathrm{Ga}$ 単 独あるいは $\mathrm{A}$ との共存) のメタロシリケート触媒はメ夕ノー

ルを芳香族化する傾向があった。Feの MFI骨格構造の Al部位 への存在は，芳香族化と余剩の炭素鎖の成長を抑制して, LPG 成分への選択性を効果的に向上させることが確認された。これ らの $\mathrm{Fe}$ の状態の触媒性能への影響は, イオン, 金属, 酸化物 および骨格共存メタロシリケートを比べることによって，骨格 に $\mathrm{Al}$ と共存する $\mathrm{Fe}$ が最も効果的であることが明らかとなった。 骨格での $\mathrm{Fe}$ の $\mathrm{Al}$ との共存は活性劣化も抑制することが明らか となった。
\end{abstract}

